Article

\title{
Antioxidant Purple Corn Protein Concentrate from Germinated Andean Purple Corn Seeds
}

\author{
Edgar Vilcacundo ${ }^{1}$, Antón García ${ }^{2}{ }^{\odot}$, Mario Vilcacundo ${ }^{3}$, Roberto Morán ${ }^{1} \oplus$, Iván Samaniego ${ }^{4}$ \\ and Wilman Carrillo $1, *$ (D) \\ 1 Departamento de Investigación, Universidad Estatal de Bolívar, 020102 Guaranda, Bolívar, Ecuador; \\ mvilcacundo@ueb.edu.ec (E.V.); rmoran@ueb.edu.ec (R.M.) \\ 2 Campus Universitario de Rabanales, Departamento de Producción Animal, Universidad de Córdoba, \\ 14071 Córdoba, Spain; pa1gamaa@uco.es \\ 3 Facultad de Ciencias de la Salud, Universidad Técnica de Ambato, Calle Colombia 02-11, 180150 Ambato, \\ Ecuador; mf.vilcacundo@uta.edu.ec \\ 4 National Institute of Agricultural Research (INIAP), Santa Catalina Experimental Station, Department of \\ Nutrition and Quality, 170516 Mejía, Ecuador; ivan.samaniego@iniap.gob.ec \\ * Correspondence: wi.carrillo@uta.edu.ec; Tel.: +593-980-281-086
}

Received: 13 July 2020; Accepted: 26 August 2020; Published: 29 August 2020

\begin{abstract}
Ecuador Andean purple corn (Zea mays L.) was subjected to a germination process at $15-40^{\circ} \mathrm{C}$ for 24-168 incubation hours. Purple corn protein concentrates (PCPCs) were obtained by alkaline extraction at $\mathrm{pH} 8.0$ and $\mathrm{pH} 10.0$, followed by an isoelectric precipitation process at $\mathrm{pH} 4.0, \mathrm{pH} 5.0$ and $\mathrm{pH}$ 6.0. Proteins and phenolic content of PCPCs was calculated. PCPC antioxidant properties were determined by the ferric-reducing antioxidant power (FRAP) in vitro method and by the 2,2-azinobis, 3-ethyl-benzothiazoline-6-sulfonic acid, (ABTS) in vitro method. Andean purple corn seeds were able to germinate under the germination conditions tested in this study. The higher percentage of germination was of $63.33 \%$ at $168 \mathrm{~h} / 25{ }^{\circ} \mathrm{C}$. The PCPCs protein profile was characterized for the presence of six bands with molecular weights of $14.50 \mathrm{kDa}, 20.12 \mathrm{kDa}, 25.18 \mathrm{kDa}, 41.85 \mathrm{kDa}, 59.59 \mathrm{kDa}$, and $65.87 \mathrm{kDa}$. Germinated PCPC presented a high TPC content with ranges of $605.71-1820.00 \mathrm{mg}$ gallic acid equivalents (GAE)/g PCPC dry weight (DW), germinated PCPC/72 h/25 ${ }^{\circ} \mathrm{C}$ presented a higher value of $1820.00 \mathrm{mg}$ GAE/g PCPC, DW. All germinated PCPCs samples assayed presented strong antioxidant activity when measured by the ABTS and FRAP methods. Germinated PCPC/144 h/35 ${ }^{\circ} \mathrm{C}$ presented high antioxidant activity by ABTS with $804.35 \mu \mathrm{mol}$ Trolox equivalents (TE)/g PCPC DW and germinated PCPC $/ 144 \mathrm{~h} / 30^{\circ} \mathrm{C}$ presented a high value by the FRAP method, $987.83 \mu \mathrm{mol} \mathrm{TE} / \mathrm{g}$ PCPC DW.
\end{abstract}

Keywords: Andean purple corn; Zea mays; purple corn protein concentrate; germinated; antioxidant activity

\section{Introduction}

Corn (Zea mays L) stands at third place in importance of cereal crops after wheat and rice with 1147 million tons of fresh weight of seeds produced in 193 million hectares during 2018 [1]. In Ecuador, corn is one of the main crops in the Andean region. In 2018, more than 365,334 hectares were harvested with a total production of 1,324,147 tons. This represents an average yield of $3.62 \mathrm{t} / \mathrm{ha}$ [1]. Corn belongs to the Family Poaceae and Genus Zea [2,3]. There are several types of corn grains with different colors such as yellow, blue, brown, green, and purple. Purple corn, also called purple maize, is a native crop of the Andean region in South America cultivated in Peru, Ecuador, Bolivia, and Argentina $[4,5]$. Maize is a cereal crop widely spread throughout the world from latitude $580 \mathrm{~N}$ to $400 \mathrm{~S}$, from sea 
level up to more than $3000 \mathrm{~m}$ of altitude and in areas with an annual rainfall between $250 \mathrm{~mm}$ and $5000 \mathrm{~mm}$ [6]. The countries with major corn production in the world are the USA with $30 \%$, China $15 \%$, EU 14\%, Brazil 4\%, and India 3\% [6]. Corn is used for animal and human food for their chemical composition and a high nutritive value. Corn grains have a high starch content (72\%), $7-13 \%$ protein content, $2.5 \%$ of fiber, and $4.8 \%$ of oil content. Corn grains have an important content of vitamins and minerals [7-11].

Germination is a biological process that allows plants to use seeds to conserve species. With this process, a series of biological mechanisms are initiated that allow the growth of an embryo. The embryos begin germination with the entry of water and end with the elongation of the embryo axis-terminal. During this complex process, different biological compounds of the seeds undergo catabolism and synthesis processes [12-14]. In the early stages, many of the phytocompounds are used for embryo growth. The synthesis of new phytocompounds used for different purposes including protection mechanisms is activated. In addition, during germination, the seeds reduce some components that are considered anti-nutrients (phytic acid and lectins) [15-18].

At the biotechnological level, sprouts are used to generate germplasm banks. For many years, sprouts have attracted the interest of the food industry for the nutritional value of their components and their biological properties such as the antioxidant activity [19]. Antioxidant compounds are used in the food industry to preserve processed foods against lipid oxidation [20-22]. Recent studies have demonstrated their inhibitory effects against certain diseases such as cancer $[23,24]$. Therefore, there is a considerable interest in the search for natural compounds with antioxidant properties [25-27]. Many natural extracts obtained from plants containing mainly polyphenols, flavonoids, carotenes, and anthocyanins have been described in the scientific literature for their high antioxidant activity [28,29].

Sprouts can be a natural alternative to obtain compounds with antioxidant capacity (polyphenols and proteins). Different sprouts have been described with biological activities, lentils (Lens culinaris), soy (Glycine max), amaranth (Amaranthus caudatus), quinoa (Chenopodium quinoa Willd), and beans (Phaseolus vulgaris) [30-35]. Piñuel et al., 2019 described protein isolates of sprouts and hydrolysates obtained from quinoa seeds (Chenopodium quinoa Willd) with high antioxidant capacity [36]. The objective of this work was to determine the germinations conditions of Andean purple corn seeds to produce purple corn protein concentrate ( $\mathrm{PCPC}$ ) and to evaluate their antioxidant activity using the 2,2-azinobis, 3-ethyl-benzothiazoline-6-sulfonic acid, (ABTS) and ferric-reducing antioxidant power (FRAP) methods.

\section{Material and Methods}

\subsection{Chemicals Reactive}

Folin-Ciocalteu reagent, gallic acid standard, 2, 20-Azino-bis-(3-ethylbenzothiazoline-6-sulfonic acid) (ABTS), 2,2-diphenyl-1-picrylhydrazyl (DPPH), and 6-Hydroxy-2,5,7,8-tetramethylchroman-2 -carboxylic acid (Trolox standard) were obtained from Sigma-Aldrich (St. Louis, MO, USA).

\subsection{Plant Material}

Andean purple corn seeds (Zea mays L., INIAP-199 bunch of grapes) were collected from 40 corn plants of the crop grown by the Bolivar State University (Guaranda), and the National Institute of Agricultural Research (INIAP), (Quito). The crop was grown in the city of Guaranda, Bolivar in Ecuador at an altitude of $2800 \mathrm{~m}$, south latitude $01^{\circ} 34^{\prime} 15^{\prime \prime}$ and west longitude $79^{\circ} 0^{\prime} 02^{\prime \prime}$. The average annual temperature of the site is $13{ }^{\circ} \mathrm{C}$ with $75 \%$ humidity. The harvest was carried out by hand once the seeds reached physiological and commercial maturity. The seeds were manually shelled and dried in a drying rack in the open air until reaching a humidity of $14 \%$. Then, they were stored in plastic containers. 


\subsection{Proximal Analysis of Purple Corn Flour}

The chemical composition of purple corn flour was analyzed according to standard protocols. Fat was analyzed according to AOAC 2003.06:2012, moisture AOAC 925.10:2012 [37], fiber INEN 522:2013, ash INEN 520:2013 [38], and protein with the Dumas method.

\subsection{Germination of Purple Corn Seeds}

Andean purple corn seeds were germinated according to the methodology described by Paucar-Menacho et al. (2016) [39]. One hundred seeds were submerged for disinfection in $0.1 \%$ sodium hypochlorite solution (1:5 p/v) for $30 \mathrm{~min}$ at room temperature and then washed with distilled water. The seeds were then submerged in distilled water $(1: 5 p / v)$ at room temperature for $24 \mathrm{~h}$. Subsequently, the hydrated seeds were introduced to the BINDER KBF 240 (LabReCo, Horsham, PA, USA) constant climate chamber on wet filter paper, with a water circulation system to always keep the seeds moist. Germination was carried out in the dark at the following temperatures with durations of $24 \mathrm{~h}, 48 \mathrm{~h}, 72 \mathrm{~h}, 96 \mathrm{~h}, 120 \mathrm{~h}, 144 \mathrm{~h}$, and $168 \mathrm{~h}$. Three replications were made for each germination condition. The percentage of germination was calculated to each treatment of germination. The percentage of germination $=(\%$ normal seeds $+\%$ anormal seeds $+\%$ dead seeds $)$ $=100 \%$. Normal seeds were evaluated as good ridicule, primary roots and secondary roots well grow; hypocotyl well grow; plumule with good development, with leaves well grow and a healthy cotyledon. Abnormal seeds were evaluated as damaged primary root and absence of secondary roots and cotyledons and leaves deformed, necrotic, or damaged by infections.

\subsection{Purple Corn Protein-Phenolic Concentrate (PCPC) from Germinated Seeds}

Germinated and non-germinated Andean purple corn seeds were ground in a Perten 120 laboratory mill (Perten Instruments, Hägersten, Sweden) until a flour $(<500 \mathrm{~mm})$ was obtained. Purple corn flour defatted $(10 \mathrm{~g})$ was resuspended in $100 \mathrm{~mL}$ of Milli-Q water. The $\mathrm{pH}$ of the solution was adjusted to $\mathrm{pH} 8.0$ and $\mathrm{pH} 10.0$ with $2.0 \mathrm{M} \mathrm{NaOH}$. The solution obtained was shaken for $60 \mathrm{~min}$ and centrifuged at $10,000 \times g$ for $60 \mathrm{~min}$ at $4{ }^{\circ} \mathrm{C}$. The precipitate obtained was separated and discarded (fiber, ash, and carbohydrates). The $\mathrm{pH}$ of the supernatant was adjusted to $\mathrm{pH} 4.0, \mathrm{pH} 5.0$ and $\mathrm{pH} 6.0$ with $1 \mathrm{NHCl}$. The supernatant solutions were centrifuged at $10,000 \times \mathrm{g}$ for $30 \mathrm{~min}$ at $4{ }^{\circ} \mathrm{C}$. The $\mathrm{pH}$ of the precipitate obtained was adjusted to $\mathrm{pH} 7.0$ using a $0.5 \mathrm{M} \mathrm{NaOH}$ solution. PCPC samples produced were dried by a lyophilization technique and frozen and stored at $-80^{\circ} \mathrm{C}$ [40]. PCPC protein content was calculated by the Dumas method using a macro elemental analyzer (Elemental Vario Macro Cube, Langenselbold, Germany). The PCPC protein percentage was determined with the equation $\%$ of protein $=6.25 \times \% \mathrm{~N}$, where 6.25 is the conversion factor and $\mathrm{N}$ is the percentage of nitrogen determined by the instrument [41].

\subsection{PCPC Electrophoresis Analysis}

PCPC proteins profile was characterized by the sodium dodecyl sulfate-polyacrylamide gel electrophoresis (SDS-PAGE) method using a mini-protean cell electrophoresis system (Bio-Rad, Hercules, CA, USA). The gels were prepared with a concentration of $12.00 \%$ polyacrylamide. The tinting of gels of polyacrylamide was made using a Coomassie Brilliant Blue G-250 solution for $24 \mathrm{~h}$ with shacked up. PCPC protein molecular weight was calculated with the help of Gel Documentation Imagen systems (Analytic Jena Tower, Jena Germany). A marker of standard with molecular weights of $10 \mathrm{kDa}-200 \mathrm{kDa}$ (Bio-Rad, Hercules, CA, USA) was used [42].

\subsection{PCPC Quantification of Total Phenolic Content (TPC)}

The samples for TPC analysis were extracted in all PCPCs samples. The TPC was extracted using methanol (70\%) from lyophilized PCPC and stirred for $5 \mathrm{~min}$, followed by an ultrasound technique for $10 \mathrm{~min}$. The extracts were centrifuged, filtered, and calibrated. An aliquot of the solution was 
separated and mixed with distilled water, Folin Ciocalteau reagent, and with sodium carbonate (20\%). The samples absorbance was measured at $765 \mathrm{~nm}$. TPC quantification was made with a standard calibration curve of gallic acid (GA). The standard curve obtained was ( $\left.y=0.0021 x+0.0033, R^{2} 0.9982\right)$. TPC results were expressed as mg gallic acid equivalents GAE/g of PCPC, DW [43].

\subsection{Assay of Antioxidant Activity by ABTS Method}

Germinated PCPCs $(200 \mu \mathrm{L})$ were mixed with $3800 \mu \mathrm{L}$ of ABTS solution (composed of $7 \mathrm{mM}$ ABTS solution with $2.45 \mathrm{mM}$ potassium persulfate solution in a 1:1 ratio) and then diluted with phosphate buffer until obtaining an absorbance of $1.1 \pm 0.01$ a $743 \mathrm{~nm}$. For the determination of the concentrations, a calibration curve was performed with the Trolox standard solution $(200 \mu \mathrm{mol}$ to $1000 \mu \mathrm{mol})$. The curve obtained was $\left(\mathrm{y}=0.012 \mathrm{x}+0.2089, \mathrm{R}^{2}=0.9901\right)$. The data were expressed as $\mu$ mol of trolox equivalents TE/g PCPC, DW [44].

\subsection{Assay of Antioxidant Activity by the Ferric-Reducing Antioxidant Power (FRAP) Method}

Germinated PCPCs $(1 \mathrm{~mL})$ were mixed with $2.5 \mathrm{~mL}$ of $\mathrm{pH} 6.6$ buffer solution. $5 \mathrm{~mL}$ of $1 \%$ potassium ferrocyanide solution was added. The sample was incubated in a water bath at $50{ }^{\circ} \mathrm{C}$ for $20 \mathrm{~min}$. Then, $2.5 \mathrm{~mL}$ of $10 \%$ trichloroacetic acid solution, $2.5 \mathrm{~mL}$ of distilled water and $0.5 \mathrm{~mL}$ of $1 \%$ ferric chloride were added. Samples and standards were homogenized in a vortex and rested for $30 \mathrm{~min}$ in the dark. Finally, the absorbance of the solutions was measured at $700 \mathrm{~nm}$.

For the determination of the concentrations, a calibration curve was performed with the Trolox standard $(200 \mu \mathrm{mol}$ to $1000 \mu \mathrm{mol})$. The curve obtained was $\left(\mathrm{y}=0.0016 \mathrm{x}+0.1324, \mathrm{R}^{2}=0.9985\right)$. The data were expressed as $\mu \mathrm{mol}$ of trolox equivalents TE/g of PCPC, DW [45].

\subsection{Statistical Analysis}

Results were presented as mean \pm standard deviation $(n=3)$. Statistical differences of the samples were evaluated with one-way ANOVA analysis $(p<0.05)$ followed by the Tukey test. The statistical differences were presented with a different letter.

\section{Results and Discussion}

\subsection{Purple Corn Flour Proximal Analysis}

Proximal analysis of purple corn flour showed that protein content was $8.58 \pm 0.07 \%$, fat content $5.73 \pm 0.10 \%$, ash content $0.02 \pm 0.00 \%$, moisture content $11.70 \pm 0.05 \%$, fiber content $2.91 \pm 0.26 \%$, and carbohydrates content $71.06 \pm 0.16 \%$. Their composition depends on the environmental conditions of the cultivars, temperature, variety, and type of seeds (yellow, white, black, blue, and purple seeds). Trehan et al. (2018) reported the chemical composition of three varieties of white, yellow, and purple corn flours. They reported a fat content for yellow corn flour (2.85-5.23\%), white corn flour (2.03-4.95\%), and purple corn flour (1.70-4.61\%). They reported protein content of yellow, white, and purple corn flour (8.44-8.70\%), (8.73-9.54\%), and (9.53-9.88\%), respectively [46]. Mansilla et al. (2020) reported different genotypes of purple corn cultivars from Argentina with protein contents between $9.48 \%$ to $11.50 \%$ and fat contents between $6.72 \%$ and $8.21 \%$ [47]. The results of protein content of purple corn flour reported in this study were lower than those reported by the other researchers, while the fat content was higher.

\subsection{Germination (\%) of Purple Corn Seeds}

Andean purple corn (100 seeds) were put in the germination process in the incubator for $24 \mathrm{~h}$, $48 \mathrm{~h}, 72 \mathrm{~h}, 96 \mathrm{~h}, 120 \mathrm{~h}, 144 \mathrm{~h}$, and $168 \mathrm{~h}$ at $15{ }^{\circ} \mathrm{C}, 20^{\circ} \mathrm{C}, 25{ }^{\circ} \mathrm{C}, 30^{\circ} \mathrm{C}, 35^{\circ} \mathrm{C}$, and $40{ }^{\circ} \mathrm{C}$. Table 1 showed the germination percentage obtained at different conditions. Germination percentages were obtained with values between $0.00 \pm 0.00$ and $63.33 \pm 7.23$. The highest germination percentages were obtained at the temperature of $25{ }^{\circ} \mathrm{C}$ with germination values between $42.00 \%$ and $63.33 \%$. 
The seeds incubated at $15^{\circ} \mathrm{C}$ for $24 \mathrm{~h}$ to $96 \mathrm{~h}$ did not showed germination. At $120 \mathrm{~h}$, they presented a $6.00 \pm 0.58 \%$ of germination. These values increased with a germination time of $168 \mathrm{~h}$, presenting the highest percentage with a value of $63.33 \%$. The increase in $\%$ of germination was proportional to the increase in the incubation time of the seeds to germinate. As the germination temperature increases, the germination percentage decreases. The germinated rates obtained at $40{ }^{\circ} \mathrm{C}$ varied between $9.33 \%$ and $26.00 \%$. These were the lowest values of germination obtained.

The results obtained present significant differences at $p<0.05$ when compared to incubation temperature with time of incubation of germination of the Andean purple corn seeds. Govender, Aveling, and Kritzinger (2007) reported percentages of germination of yellow and white varieties from northern KwaZulu-Natal and southern Mozambique with values of 18.70 to $100 \%$ depending on the variety. Germination process was made at $25^{\circ} \mathrm{C}$ for $7-11$ days [8].

Figure 1 showed the registered pictures of the Andean purple corn germinated obtained at different temperatures and different germination times. Figure $1 \mathrm{a}, \mathrm{b}$ showed the seeds germinated at $20^{\circ} \mathrm{C}$ and $25^{\circ} \mathrm{C}$ during $72 \mathrm{~h}, 96 \mathrm{~h}, 120 \mathrm{~h}, 144 \mathrm{~h}$, and $168 \mathrm{~h}$ of incubation. All the seeds showed clear signs of germination with lifting of the cotyledons and elongation of the radicles. Figure $1 \mathrm{c}$ showed the purple corn seeds germinated at $30^{\circ} \mathrm{C}, 35^{\circ} \mathrm{C}$, and $40{ }^{\circ} \mathrm{C}$ for $168 \mathrm{~h}$. In the pictures, a clear germination process is observed, and the embryos showed elongation of the radicles. Germinated kernels at $30^{\circ} \mathrm{C}$ and $35^{\circ} \mathrm{C}$ have clear leaves and roots. The germinated purple corn at $40{ }^{\circ} \mathrm{C}$ obtained at the same time showed a delay in germination.

a)

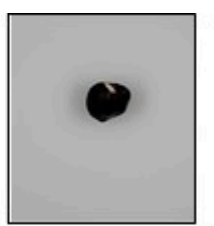

$72 \mathrm{~h}$

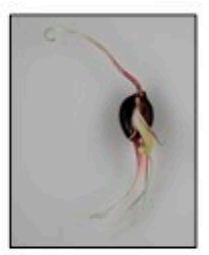

$72 \mathrm{~h}$

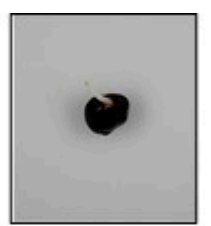

$96 \mathrm{~h}$

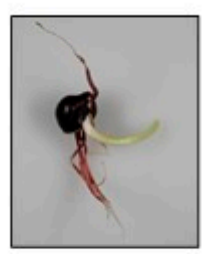

$96 \mathrm{~h}$

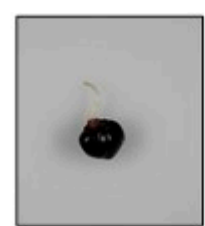

$120 \mathrm{~h}$

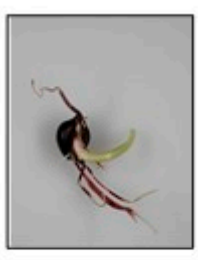

$120 \mathrm{~h}$

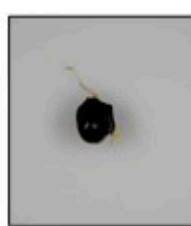

$144 \mathrm{~h}$

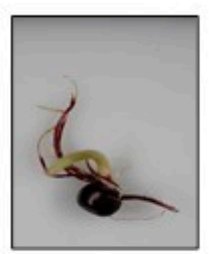

$144 \mathrm{~h}$

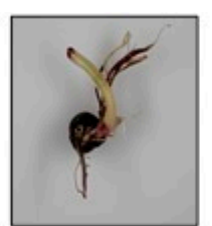

$168 \mathrm{~h}$

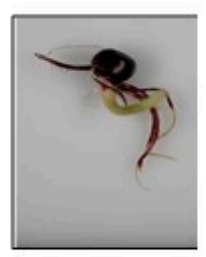

$168 \mathrm{~h}$ $20^{\circ} \mathrm{C}$

$25^{\circ} \mathrm{C}$

$168 \mathrm{~h}$

c)

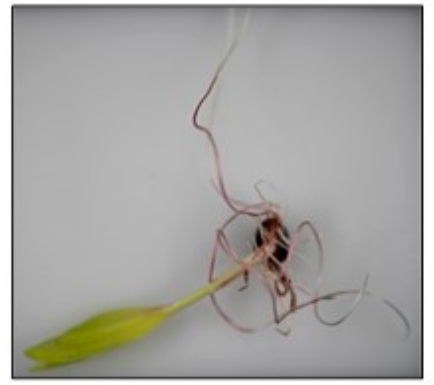

$30^{\circ} \mathrm{C}$

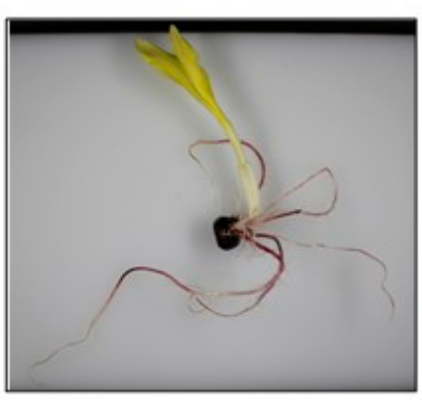

$35^{\circ} \mathrm{C}$

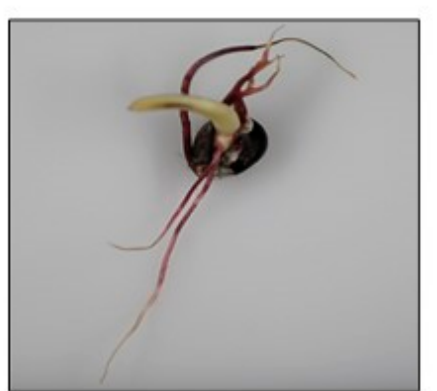

$40^{\circ} \mathrm{C}$

Figure 1. Pictures of germination of Andean purple corn. (a) Germination of purple corn seeds at $20^{\circ} \mathrm{C}$ for $72,96,120,144$, and $168 \mathrm{~h}$; (b) germination of purple corn seeds at $25^{\circ} \mathrm{C}$ for $72,96,120,144$, and $168 \mathrm{~h}$; (c) germination of purple corn seeds at $30^{\circ} \mathrm{C}, 35^{\circ} \mathrm{C}$, and $40^{\circ} \mathrm{C}$ for $168 \mathrm{~h}$. 
Table 1. Percentage germination at different time and temperature combinations of Andean purple corn seeds.

\begin{tabular}{ccccccc}
\hline \multicolumn{7}{c}{ \% of Germination of Andean Purple Corn Seeds } \\
\hline Time (h) & $\mathbf{1 5}^{\circ} \mathbf{C}$ & $\mathbf{2 0}{ }^{\circ} \mathbf{C}$ & $\mathbf{2 5}^{\circ} \mathbf{C}$ & $\mathbf{3 0}^{\circ} \mathbf{C}$ & $\mathbf{3 5}^{\circ} \mathbf{C}$ & $\mathbf{4 0}^{\circ} \mathbf{C}$ \\
\hline 24 & $0.00 \pm 0.00$ & $0.00 \pm 0.00$ & $3.33 \pm 0.58^{\mathrm{a}}$ & $9.00 \pm 3.56^{\mathrm{a}}$ & $20.67 \pm 4.04^{\mathrm{a}}$ & $9.33 \pm 2.08^{\mathrm{a}}$ \\
48 & $0.00 \pm 0.00$ & $3.33 \pm 0.71^{\mathrm{a}}$ & $42.00 \pm 7.55^{\mathrm{b}}$ & $33.00 \pm 3.54^{\mathrm{b}}$ & $36.67 \pm 4.73^{\mathrm{b}}$ & $22.67 \pm 2.08^{\mathrm{b}}$ \\
72 & $0.00 \pm 0.00$ & $24.00 \pm 6.24^{\mathrm{b}}$ & $52.67 \pm 8.74^{\mathrm{c}}$ & $37.00 \pm 3.54^{\mathrm{b}}$ & $38.00 \pm 5.29^{\mathrm{b}}$ & $23.33 \pm 2.52^{\mathrm{b}}$ \\
96 & $0.00 \pm 0.00$ & $38.67 \pm 4.62^{\mathrm{c}}$ & $54.00 \pm 8.19^{\mathrm{c}}$ & $41.00 \pm 3.54^{\mathrm{c}}$ & $38.67 \pm 5.69^{\mathrm{b}}$ & $23.33 \pm 2.52^{\mathrm{b}}$ \\
120 & $6.00 \pm 0.58^{\mathrm{a}}$ & $46.67 \pm 7.43^{\mathrm{d}}$ & $58.67 \pm 8.39^{\mathrm{d}}$ & $41.00 \pm 3.54^{\mathrm{c}}$ & $38.67 \pm 5.69^{\mathrm{b}}$ & $23.33 \pm 2.52^{\mathrm{b}}$ \\
144 & $6.00 \pm 0.58^{\mathrm{a}}$ & $53.33 \pm 4.51^{\mathrm{e}}$ & $60.00 \pm 8.66^{\mathrm{d}}$ & $41.00 \pm 3.54^{\mathrm{c}}$ & $40.00 \pm 4.58^{\mathrm{c}}$ & $26.00 \pm 2.00^{\mathrm{c}}$ \\
168 & $6.00 \pm 0.58^{\mathrm{a}}$ & $56.00 \pm 4.58^{\mathrm{e}}$ & $63.33 \pm 7.23^{\mathrm{e}}$ & $41.00 \pm 3.54^{\mathrm{c}}$ & $40.00 \pm 4.58^{\mathrm{c}}$ & $26.00 \pm 2.00^{\mathrm{c}}$ \\
\hline
\end{tabular}

Results were expressed as mean \pm standard deviation $(n=3)$ and were evaluated by one-way Anova and Turkey test $(p<0.05)$. Statistical differences were indicated with different letters. Temperatures groups were compared with times groups.

\subsection{PCPCs Protein Profile}

Once germinated, the Andean purple corn seeds were used to obtain flour. The flour was used to obtain protein-phenolic concentrates by alkaline extraction $(\mathrm{pH} 8.0$ and $\mathrm{pH} 10.0)$ followed by isoelectric precipitation ( $\mathrm{pH} 4.0, \mathrm{pH} 5.0$, and $\mathrm{pH}$ 6.0). Once the PCPCs were obtained, their protein profile was analyzed using the SDS-APGE technique. Figure 2 showed the PCPC protein profile. Figure 2a showed the PCPC profile of non-germinated seeds (control). Six bands with molecular weights of $14.50 \mathrm{kDa}$, $20.12 \mathrm{kDa}, 25.18 \mathrm{kDa}, 41.85 \mathrm{kDa}, 59.59 \mathrm{kDa}$, and $65.87 \mathrm{kDa}$ were observed in the gel of polyacrylamide. These bands correspond to albumins, globulins, and glutelin. The prolamins in corn are named zeins and represent around $60.00 \%$ of the protein in the corn seeds (fresh weight). Zeins can be divided into four subfamilies: $\alpha$ (19 and $22 \mathrm{kDa}), \gamma(50,27$, and $16 \mathrm{kDa}), \beta(15 \mathrm{kDa})$, and $\delta(18$ and $10 \mathrm{kDa})$ [48-50]. The protein profile of non-germinated PCPCs produced at $\mathrm{pH} 8.0$ and $\mathrm{pH} 10.0$ at different precipitation $\mathrm{pHs}(\mathrm{pH}$ 4.0, $\mathrm{pH}$ 5.0, and $\mathrm{pH}$ 6.0) was the same (Figure 2a). PCPCs (pH 8.0 and 10 alkaline and $\mathrm{pH} 4.0$ isoelectric precipitation) obtained from seeds germinated at $20^{\circ} \mathrm{C}, 25^{\circ} \mathrm{C}, 30^{\circ} \mathrm{C}, 35^{\circ} \mathrm{C}$, and $40^{\circ} \mathrm{C}$ for $72 \mathrm{~h}$ presented the same bands with identical molecular weights to those identified in the non-germinated PCPC with values of $14.50 \mathrm{kDa}, 20.12 \mathrm{kDa}, 25.18 \mathrm{kDa}, 41.85 \mathrm{kDa}, 59.59 \mathrm{kDa}$, and $65.87 \mathrm{kDa}$ (Figure 2b,c).

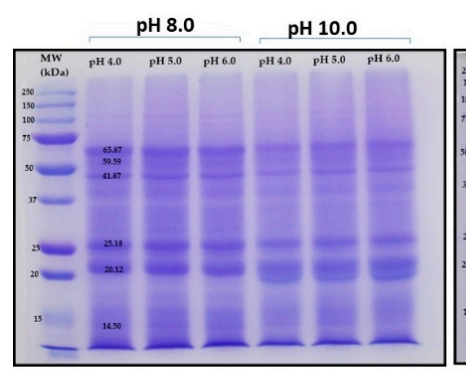

Non- Germinated PCPC

a)

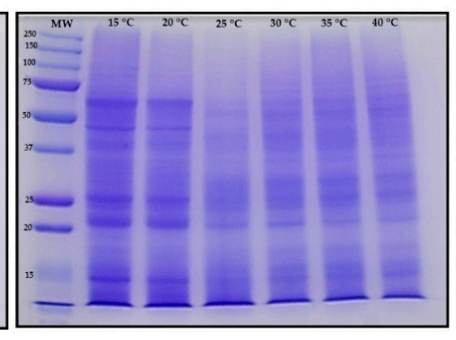

72 h Germinated PCPC

b)

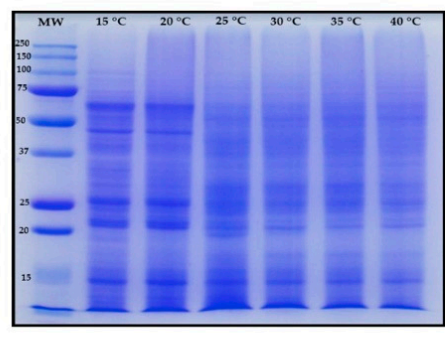

72 h Germinated PCPC

c)

Figure 2. Analysis of protein profile of purple corn protein phenolic concentrates (PCPC) by sodium dodecyl sulfate-polyacrylamide gel electrophoresis (SDS-PAGE). (a) Non-germinated PCPC obtained at ( $\mathrm{pH} 8.0$ and $\mathrm{pH} 10$ alkaline extraction) and different $\mathrm{pHs}$ of precipitation; (b) germinated PCPC at ( $\mathrm{pH} 8.0$ alkaline and $\mathrm{pH} 4.0$ of precipitation) for $72 \mathrm{~h}$; (c) germinated PCPC at (pH 10 and $\mathrm{pH} 4.0$ of precipitation) for $72 \mathrm{~h}$.

\subsection{PCPCs Protein Content Quantification}

The protein content present in PCPCs obtained from germinated seeds at $72 \mathrm{~h}, 120 \mathrm{~h}$, and $168 \mathrm{~h}$ incubated at $15{ }^{\circ} \mathrm{C}, 20^{\circ} \mathrm{C}, 25^{\circ} \mathrm{C}, 30^{\circ} \mathrm{C}, 35^{\circ} \mathrm{C}$, and $40^{\circ} \mathrm{C}$ was quantified using the Dumas method. Table 2 summarizes the results obtained from the protein quantification analysis. Protein concentration in PCPCs ranges between 9.38\% (8.0-6.0 pH (alkaline-Ip)) to 33.56\% (10.0-4.0 pH (alkaline-Ip)) these 
values correspond to PCPC germinated at $25^{\circ} \mathrm{C}$. The highest value was obtained after $168 \mathrm{~h}$ of incubation. The PCPCs obtained at the two extraction $\mathrm{pHs}(\mathrm{pH} 8.0$ and $\mathrm{pH} 10.0)$ present similar protein percentage values. Small differences were observed in PCPCs from sprouts $72 \mathrm{~h} / 25^{\circ} \mathrm{C}, 120 \mathrm{~h} / 20^{\circ} \mathrm{C}$, and $120 \mathrm{~h} / 25^{\circ} \mathrm{C}$. The highest values obtained were PCPC $168 \mathrm{~h} / 25^{\circ} \mathrm{C}$ with values of $29.06 \%, 30.00 \%$, and $33.56 \%$; PCPC $168 \mathrm{~h} / 30{ }^{\circ} \mathrm{C}$ presented values of $23.75 \%, 27.53 \%$, and $29.38 \%$; PCPC $168 \mathrm{~h} / 35{ }^{\circ} \mathrm{C}$ presented percentages of $23.80 \%, 27.60 \%$, and $29.40 \%$. All PCPCs obtained from germinated corn seeds at different times and different temperatures presented protein percentage values higher than the percentage of corn flour from non-germinated corn seeds $(8.53 \%)$. Statistical analysis indicates significant differences when the time of germination was compared to the $\mathrm{pHs}$ alkaline and the isoelectric precipitation at $p<0.05$.

Table 2. PCPC protein content in germinated Andean purple corn.

\begin{tabular}{|c|c|c|c|}
\hline pH (Alkaline-Ip) & $72 \mathrm{~h}$ & $120 \mathrm{~h}$ & $168 \mathrm{~h}$ \\
\hline \multicolumn{4}{|c|}{$\%$ Protein-germinated $15^{\circ} \mathrm{C}$} \\
\hline $8.0-4.0$ & $25.16 \pm 0.57^{b}$ & $21.81 \pm 0.18^{a}$ & $24.00 \pm 0.53^{c}$ \\
\hline $8.0-5.0$ & $24.09 \pm 0.22^{a}$ & $21.97 \pm 0.22^{a}$ & $23.06 \pm 0.44^{b}$ \\
\hline $8.0-6.0$ & $24.00 \pm 0.09^{a}$ & $21.94 \pm 0.09^{a}$ & $21.06 \pm 0.45^{\mathrm{a}}$ \\
\hline $10.0-4.0$ & $27.16 \pm 0.13^{c}$ & $24.88 \pm 0.00^{\mathrm{c}}$ & $25.31 \pm 0.62^{d}$ \\
\hline $10.0-5.0$ & $26.34 \pm 0.04^{c}$ & $24.34 \pm 0.14^{c}$ & $23.91 \pm 0.49^{b}$ \\
\hline $10.0-6.0$ & $24.34 \pm 0.75^{a}$ & $22.00 \pm 0.35^{b}$ & $23.06 \pm 0.32^{b}$ \\
\hline \multicolumn{4}{|c|}{$\%$ Protein-germinated $20^{\circ} \mathrm{C}$} \\
\hline $8.0-4.0$ & $23.16 \pm 0.04^{b}$ & $18.63 \pm 0.18^{b}$ & $25.72 \pm 0.04^{c}$ \\
\hline $8.0-5.0$ & $22.56 \pm 0.00^{b}$ & $23.44 \pm 0.09 \mathrm{~d}$ & $16.84 \pm 0.04^{\mathrm{a}}$ \\
\hline $8.0-6.0$ & $20.31 \pm 0.09^{a}$ & $16.50 \pm 0.00^{a}$ & $22.08 \pm 0.02^{b}$ \\
\hline $10.0-4.0$ & $23.50 \pm 0.00^{b}$ & $27.06 \pm 0.17^{e}$ & $28.19 \pm 0.00^{d}$ \\
\hline $10.0-5.0$ & $22.97 \pm 0.13^{b}$ & $24.22 \pm 0.13^{d}$ & $24.48 \pm 0.07^{\mathrm{c}}$ \\
\hline $10.0-6.0$ & $20.09 \pm 0.05^{a}$ & $21.88 \pm 0.08^{c}$ & $22.53 \pm 0.04^{b}$ \\
\hline \multicolumn{4}{|c|}{$\%$ Protein-germinated $25^{\circ} \mathrm{C}$} \\
\hline $8.0-4.0$ & $17.78 \pm 0.13^{c}$ & $10.69 \pm 0.18^{a}$ & $22.16 \pm 3.14^{b}$ \\
\hline $8.0-5.0$ & $18.69 \pm 0.09^{d}$ & $9.44 \pm 0.18^{a}$ & $19.09 \pm 0.13^{a}$ \\
\hline $8.0-6.0$ & $18.25 \pm 0.18^{\mathrm{d}}$ & $9.38 \pm 0.09^{a}$ & $19.75 \pm 0.35^{\mathrm{a}}$ \\
\hline $10.0-4.0$ & $14.88 \pm 0.17^{b}$ & $27.50 \pm 0.09 \mathrm{~d}$ & $33.56 \pm 1.94^{\mathrm{d}}$ \\
\hline $10.0-5.0$ & $13.19 \pm 0.04^{\mathrm{a}}$ & $16.88 \pm 0.08^{c}$ & $29.06 \pm 1.33^{c}$ \\
\hline $10.0-6.0$ & $13.00 \pm 0.18^{a}$ & $12.47 \pm 0.04^{b}$ & $30.00 \pm 0.44^{c}$ \\
\hline \multicolumn{4}{|c|}{$\%$ Protein-germinated $30^{\circ} \mathrm{C}$} \\
\hline $8.0-4.0$ & $26.56 \pm 0.09^{d}$ & $26.44 \pm 0.18^{\mathrm{d}}$ & $23.75 \pm 0.09^{c}$ \\
\hline $8.0-5.0$ & $25.19 \pm 0.22^{c}$ & $24.38 \pm 0.00^{\mathrm{c}}$ & $21.00 \pm 0.09^{b}$ \\
\hline $8.0-6.0$ & $22.66 \pm 0.09^{a}$ & $21.44 \pm 0.27^{\mathrm{a}}$ & $18.38 \pm 0.00^{\mathrm{a}}$ \\
\hline $10.0-4.0$ & $26.25 \pm 0.00^{\mathrm{d}}$ & $27.28 \pm 0.13^{d}$ & $29.38 \pm 0.09{ }^{e}$ \\
\hline $10.0-5.0$ & $26.75 \pm 0.18^{\mathrm{d}}$ & $26.50 \pm 0.00^{d}$ & $27.53 \pm 014^{d}$ \\
\hline $10.0-6.0$ & $24.19 \pm 0.00^{b}$ & $23.71 \pm 0.14^{b}$ & $19.31 \pm 0.00^{\mathrm{a}}$ \\
\hline \multicolumn{4}{|c|}{$\%$ Protein-germinated $35{ }^{\circ} \mathrm{C}$} \\
\hline $8.0-4.0$ & $26.60 \pm 0.00^{d}$ & $26.50 \pm 0.18^{c}$ & $23.80 \pm 0.09^{c}$ \\
\hline $8.0-5.0$ & $25.20 \pm 0.18^{c}$ & $24.34 \pm 0.04^{b}$ & $21.06 \pm 0.19^{b}$ \\
\hline $8.0-6.0$ & $22.60 \pm 0.04^{a}$ & $21.44 \pm 0.00^{\mathrm{a}}$ & $18.40 \pm 0.20^{a}$ \\
\hline $10.0-4.0$ & $26.25 \pm 0.09^{d}$ & $27.25 \pm 0.35^{\mathrm{c}}$ & $29.40 \pm 0.00^{\mathrm{e}}$ \\
\hline $10.0-5.0$ & $25.53 \pm 0.18^{c}$ & $26.56 \pm 0.27^{c}$ & $27.60 \pm 0.19^{d}$ \\
\hline $10.0-6.0$ & $24.19 \pm 0.00^{b}$ & $23.75 \pm 0.00^{b}$ & $19.35 \pm 0.09^{a}$ \\
\hline \multicolumn{4}{|c|}{$\%$ of Protein-germinated $40^{\circ} \mathrm{C}$} \\
\hline $8.0-4.0$ & $21.94 \pm 0.88^{b}$ & $22.75 \pm 0.09^{a}$ & $24.53 \pm 0.49^{c}$ \\
\hline $8.0-5.0$ & $20.63 \pm 0.09^{b}$ & $22.22 \pm 0.13^{a}$ & $19.94 \pm 1.06^{b}$ \\
\hline $8.0-6.0$ & $13.47 \pm 2.25^{a}$ & $22.31 \pm 0.09^{a}$ & $15.60 \pm 2.96^{\mathrm{a}}$ \\
\hline $10.0-4.0$ & $28.56 \pm 0.35^{d}$ & $26.38 \pm 0.35^{b}$ & $21.34 \pm 0.04^{b}$ \\
\hline $10.0-5.0$ & $27.03 \pm 1.64^{d}$ & $23.66 \pm 0.75^{\mathrm{a}}$ & $21.91 \pm 0.04^{b}$ \\
\hline $10.0-6.0$ & $24.13 \pm 1.77^{c}$ & $22.34 \pm 2.87^{\mathrm{a}}$ & $14.06 \pm 0.27^{\mathrm{a}}$ \\
\hline
\end{tabular}

Results were expressed as mean \pm standard deviation $(n=3)$ and were evaluated by one-way Anova and Turkey test $(p<0.05)$. Statistical differences were indicated with different letters. 
Corn seed has albumins protein that represent $8.00 \%$ of protein, DW. Albumins proteins are soluble in a water solution. Globulins protein represent $9.00 \%$ of protein soluble in salts and glutelin proteins represent $40.00 \%$ of protein, DW, which are soluble in alkaline solutions [51]. PCPC presented albumins, glutelin and globulin proteins. Normal purple corn seeds were used in this study to get germinated PCPCs. The protein contents reported in this work are in line with values reported in the literature for different zein protein concentrates. Corn protein concentrate are used for industrial applications such as adhesives, biodegradables plastics, coating (edible, moisture-resistant) for food products, cosmetic powders, dietary fibers, textile fibers, microencapsulated pesticides, microspheres, long acting matrix tablet formulations, nutrient delivery system for ruminants, high potency sweeteners, hair fixative, and other industrial purposes [52-62].

\subsection{TPC Content of Germinated PCPCS}

TPC content was determined in germinated Andean purple seeds PCPCs for $24 \mathrm{~h}, 48 \mathrm{~h}, 72 \mathrm{~h}$, $96 \mathrm{~h}, 122 \mathrm{~h}, 144 \mathrm{~h}$, and $168 \mathrm{~h}$ at $15^{\circ} \mathrm{C}, 20^{\circ} \mathrm{C}, 25^{\circ} \mathrm{C}, 30^{\circ} \mathrm{C}, 35^{\circ} \mathrm{C}$, and $40^{\circ} \mathrm{C}$. Table 3 showed the TPC value in germinated PCPCs. Geminated PCPC had a high TPC content with a range of 350.95 to 1820 mg GAE/g PCPC, DW, germinated PCPC/ $72 \mathrm{~h} / 25^{\circ} \mathrm{C}$ had a high value of $1820.00 \mathrm{mg}$ GAE/g PCPC, DW. PCPC $/ 72 \mathrm{~h} / 25^{\circ} \mathrm{C}$ had a high TPC value in the two groups (pH 8.0 and $\mathrm{pH} 10$ ) with 1820.00 , 1803.00, and $1746.00 \mathrm{mg}$ GE/g PCPC, DW for the group obtained at $\mathrm{pH} 8.0$ of extraction and 1550.00 , 1736.00, and $1426.00 \mathrm{mg} \mathrm{GAE} / \mathrm{g}$ PCPC, DW for the group $\mathrm{pH} 10 . \mathrm{PCPC} / 168 \mathrm{~h} / 35^{\circ} \mathrm{C}$ presented a TPC value of 989.05-1605.71 mg GAE/g PCPC, DW. The TPC values obtained at longer germination times and higher temperature had higher values of TPC content. The $\mathrm{pH}$ alkaline $(\mathrm{pH} 8.0$ and $\mathrm{pH} 10)$ affect the TPC content. Significant differences were observed at $p<0.05$ when were compared $\mathrm{pH}$ vs. germination time.

Mansilla et al. (2020) described purple corn growth in Argentina with TPC values between 438.00 to $1933.00 \mathrm{mg} \mathrm{GAE} / 100 \mathrm{~g}$, DW [47]. Trehan et al. (2018) described the TPC content of three varieties of yellow, white, and purple seeds corn-yellow corn (1170.00-1640.00 mg GAE/g Sample), white corn (903.00-1332.00 mg GAE/g Sample), and purple corn (1223.00-1843.00 mg GAE/g Sample) [46]. De la Parra et al. (2007) have described TPC content of five different varieties of corn seeds yellow, white, red, blue, and high carotenoid variety with values of 260.70-320.10 mg GAE/100 g DW [63]. Mora-Rochin et al. (2010) reported a TPC content of white corn flour (167.40 mg GAE/100 g, DW), blue corn (142.10 mg GAE/100 g DW), red corn (140.70 mg GAE/100 g DW), and yellow corn (137.70 mg GAE/100 g DW) [64]. PCPC concentrates from germinated kernels increased the TPC content when compared to the TPC content reported for purple corn flour.

The isoelectric precipitation $\mathrm{pH}(\mathrm{pH} 4.0, \mathrm{pH} 5.0$, and $\mathrm{pH}$ 6.0) used to precipitate the proteins allows the isolation of a considerable amount of phenolic components. PCPCs continue to maintain a purple coloration which indicated their presence in protein concentrates. Total phenolic can be separated from PCPCs with repeated methanol extractions. Six consecutive extraction processes allowed the isolation of $100.00 \%$ of the phenolic components present in the PCPCs from germinated seeds. All PCPCs tested in this work with alkaline extraction and isoelectric precipitation had a high TPC content. Future work on HPLC-MS-MS should be carried out to identify the phenolic components present in the PCPCs and to determine whether there are differences in the phenolic depending on the $\mathrm{pH}$ extraction and the $\mathrm{pH}$ precipitation.

Piñuel et al. (2019) described red bean protein concentrate (RBPC) from Phaseolus vulgaris with high antioxidant activity (ABTS and FRAP) and capacity to inhibit lipid peroxidation in the zebrafish model. They reported that RBPC had a high TPC content with values of 135.57-521.66 mg GAE/g per sample. RBPC showed antioxidant activity by ABTS with values of $81.55-257.12 \mu \mathrm{mol} \mathrm{TE} / \mathrm{g}$ of sample dependent of $\mathrm{pH}$ assayed and a FRAP value of 45.16-95.80 dependent of $\mathrm{pH}$ assayed. They reported that RBPC antioxidant activity could be due to the presence of polyphenols in RBPC [20]. 
Table 3. Total phenolic content (TPC) of germinated PCPCs.

\begin{tabular}{|c|c|c|c|c|c|c|c|}
\hline \multirow[b]{2}{*}{$\mathrm{pH}$} & \multirow[b]{2}{*}{$24 \mathrm{~h}$} & \multicolumn{6}{|c|}{ TPC (mg GAE/g PCPC, DW) } \\
\hline & & $48 \mathrm{~h}$ & $72 \mathrm{~h}$ & $96 \mathrm{~h}$ & $120 \mathrm{~h}$ & $144 \mathrm{~h}$ & $168 \mathrm{~h}$ \\
\hline \multicolumn{8}{|c|}{ TPC germinated at $15^{\circ} \mathrm{C}$} \\
\hline $8.0-4.0$ & $910.48 \pm 0.02^{b}$ & $834.29 \pm 0.02^{b}$ & $1248.57 \pm 0.11^{d}$ & $1170.00 \pm 0.11^{b}$ & $900.95 \pm 0.04^{\mathrm{a}}$ & $1205.71 \pm 0.03^{c}$ & $1289.05 \pm 0.03^{c}$ \\
\hline $8.0-5.0$ & $1029.52 \pm 0.01^{\mathrm{c}}$ & $734.29 \pm 0.01^{\mathrm{a}}$ & $1158.10 \pm 0.03^{c}$ & $1167.62 \pm 0.04^{b}$ & $943.81 \pm 0.03^{b}$ & $755.71 \pm 0.01^{\mathrm{a}}$ & $1112.86 \pm 0.03^{b}$ \\
\hline $8.0-6.0$ & $710.48 \pm 0.01^{\mathrm{a}}$ & $712.86 \pm 0.01^{\mathrm{a}}$ & $812.86 \pm 0.01^{\mathrm{a}}$ & $898.57 \pm 0.02^{\mathrm{a}}$ & $1143.81 \pm 0.02^{d}$ & $1243.81 \pm 0.03^{d}$ & $886.67 \pm 0.05^{\mathrm{a}}$ \\
\hline $10.0-4.0$ & $948.57 \pm 0.01^{\mathrm{b}}$ & $1460.48 \pm 0.01^{\mathrm{e}}$ & $1243.81 \pm 0.03^{\mathrm{d}}$ & $1379.52 \pm 0.04^{c}$ & $1172.38 \pm 0.01^{\mathrm{e}}$ & $1329.52 \pm 0.03^{\mathrm{e}}$ & $1381.90 \pm 0.02$ \\
\hline $10.0-5.0$ & $1177.14 \pm 0.02^{\mathrm{d}}$ & $1074.76 \pm 0.01 \mathrm{~d}$ & $1134.29 \pm 0.06^{c}$ & $1370.00 \pm 0.02^{c}$ & $1165.24 \pm 0.02^{\mathrm{e}}$ & $1458.10 \pm 0.05^{\mathrm{f}}$ & $1574.76 \pm 0.05$ \\
\hline $10.0-6.0$ & $1058.10 \pm 0.01^{c}$ & $984.29 \pm 0.01^{\mathrm{c}}$ & $936.67 \pm 0.03^{b}$ & $1400.95 \pm 0.04^{d}$ & $998.57 \pm 0.06^{c}$ & $962.86 \pm 0.02^{b}$ & $1196.19 \pm 0.04$ \\
\hline \multicolumn{8}{|c|}{ TPC germinated at $20^{\circ} \mathrm{C}$} \\
\hline $8.0-4.0$ & $540.32 \pm 0.01^{\mathrm{b}}$ & $613.33 \pm 0.00^{b}$ & $1248.57 \pm 0.11^{d}$ & $1170.00 \pm 0.11^{\mathrm{b}}$ & $900.95 \pm 0.04^{\mathrm{a}}$ & $1205.71 \pm 0.03^{c}$ & $1289.05 \pm 0.03^{c}$ \\
\hline $8.0-5.0$ & $621.27 \pm 0.01^{\mathrm{c}}$ & $699.05 \pm 0.01^{\mathrm{c}}$ & $1158.10 \pm 0.03^{c}$ & $1167.62 \pm 0.04^{b}$ & $943.81 \pm 0.03^{b}$ & $755.71 \pm 0.01^{\mathrm{a}}$ & $1112.86 \pm 0.03$ \\
\hline $8.0-6.0$ & $416.51 \pm 0.01^{\mathrm{a}}$ & $554.60 \pm 0.01^{\mathrm{a}}$ & $812.86 \pm 0.01^{\mathrm{a}}$ & $898.57 \pm 0.02^{a}$ & $1143.81 \pm 0.02^{\mathrm{c}}$ & $1243.81 \pm 0.03^{c}$ & $886.67 \pm 0.05^{a}$ \\
\hline $10.0-4.0$ & $694.29 \pm 0.01^{\mathrm{d}}$ & $741.90 \pm 0.01^{\mathrm{d}}$ & $1243.81 \pm 0.03^{d}$ & $1379.52 \pm 0.04^{\mathrm{c}}$ & $1172.38 \pm 0.01^{\mathrm{c}}$ & $1329.52 \pm 0.03^{d}$ & $1381.90 \pm 0.02$ \\
\hline $10.0-5.0$ & $656.19 \pm 0.01^{\mathrm{d}}$ & $591.11 \pm 0.01^{\mathrm{a}}$ & $1134.29 \pm 0.06^{c}$ & $1370.00 \pm 0.02^{\mathrm{c}}$ & $1165.24 \pm 0.02^{c}$ & $1458.10 \pm 0.05^{\mathrm{e}}$ & $1574.76 \pm 0.05$ \\
\hline $10.0-6.0$ & $614.92 \pm 0.01^{\mathrm{c}}$ & $762.54 \pm 0.01^{\mathrm{d}}$ & $936.67 \pm 0.03^{b}$ & $1400.95 \pm 0.04^{\mathrm{d}}$ & $998.57 \pm 0.06^{c}$ & $962.86 \pm 0.02^{b}$ & $1196.19 \pm 0.04$ \\
\hline \multicolumn{8}{|c|}{ TPC germinated at $25^{\circ} \mathrm{C}$} \\
\hline $8.0-4.0$ & $453.33 \pm 0.03^{b}$ & $536.67 \pm 0.02^{c}$ & $1820.00 \pm 0.01^{d}$ & $1491.43 \pm 0.03^{\mathrm{e}}$ & $1100.95 \pm 0.09 \mathrm{~d}$ & $1258.10 \pm 0.01^{\mathrm{c}}$ & $1529.52 \pm 0.02$ \\
\hline $8.0-5.0$ & $350.95 \pm 0.04^{\mathrm{a}}$ & $522.38 \pm 0.03^{c}$ & $1803.33 \pm 0.05^{d}$ & $1217.62 \pm 0.09^{b}$ & $920.00 \pm 0.05^{b}$ & $1081.90 \pm 0.01^{\mathrm{a}}$ & $1250.95 \pm 0.02$ \\
\hline $8.0-6.0$ & $1577.14 \pm 0.04^{\mathrm{f}}$ & $508.10 \pm 0.03^{b}$ & $1746.19 \pm 0.06^{c}$ & $1212.86 \pm 0.17^{b}$ & $781.90 \pm 0.04^{a}$ & $1136.67 \pm 0.01^{b}$ & $1155.71 \pm 0.03$ \\
\hline $10.0-4.0$ & $660.48 \pm 0.01^{\mathrm{d}}$ & $493.81 \pm 0.02^{b}$ & $1550.95 \pm 0.10^{b}$ & $1398.57 \pm 0.05^{\mathrm{d}}$ & $1541.43 \pm 0.04^{\mathrm{f}}$ & $1620.00 \pm 0.00^{\mathrm{e}}$ & $1315.24 \pm 0.01$ \\
\hline $10.0-5.0$ & $617.62 \pm 0.05^{c}$ & $531.90 \pm 0.02^{c}$ & $1736.67 \pm 0.08^{c}$ & $1284.29 \pm 0.09^{c}$ & $1265.24 \pm 0.01^{\mathrm{e}}$ & $1362.86 \pm 0.06^{\mathrm{d}}$ & $1436.67 \pm 0.03$ \\
\hline $10.0-6.0$ & $1172.38 \pm 0.04^{\mathrm{e}}$ & $384.29 \pm 0.02^{\mathrm{a}}$ & $1429.52 \pm 0.03^{a}$ & $1003.33 \pm 0.03^{a}$ & $972.38 \pm 0.03^{c}$ & $1284.29 \pm 0.03^{c}$ & $1355.71 \pm 0.02^{\circ}$ \\
\hline \multicolumn{8}{|c|}{ TPC germinated at $30^{\circ} \mathrm{C}$} \\
\hline $8.0-4.0$ & $1143.81 \pm 0.02^{b}$ & $993.81 \pm 0.04^{b}$ & $1217.62 \pm 0.02^{c}$ & $1222.38 \pm 0.05^{b}$ & $1324.76 \pm 0.03^{c}$ & $1277.14 \pm 0.01^{b}$ & $1265.24 \pm 0.06^{b}$ \\
\hline $8.0-5.0$ & $1179.52 \pm 0.04^{c}$ & $1150.95 \pm 0.03^{\mathrm{e}}$ & $1229.52 \pm 0.18^{c}$ & $1441.43 \pm 0.02^{\mathrm{e}}$ & $1196.19 \pm 0.02^{b}$ & $1258.10 \pm 0.01^{b}$ & $1343.81 \pm 0.03$ \\
\hline $8.0-6.0$ & $1179.52 \pm 0.04^{c}$ & $920.00 \pm 0.01^{\mathrm{a}}$ & $927.14 \pm 0.02^{\mathrm{a}}$ & $1003.33 \pm 0.01^{\mathrm{a}}$ & $1015.24 \pm 0.02^{a}$ & $950.95 \pm 0.01^{\mathrm{a}}$ & $979.52 \pm 0.04^{\mathrm{a}}$ \\
\hline $10.0-4.0$ & $1486.67 \pm 0.03^{c}$ & $1155.71 \pm 0.03^{d}$ & $1284.29 \pm 0.05^{c}$ & $1391.43 \pm 0.07^{\mathrm{d}}$ & $1472.38 \pm 0.02^{\mathrm{e}}$ & $1386.67 \pm 0.01^{\mathrm{d}}$ & $1389.05 \pm 0.07$ \\
\hline $10.0-5.0$ & $1158.10 \pm 0.01^{b}$ & $1008.10 \pm 0.05^{b}$ & $1346.19 \pm 0.06^{\mathrm{d}}$ & $1481.90 \pm 0.02^{\mathrm{e}}$ & $1408.10 \pm 0.05^{\mathrm{d}}$ & $1358.10 \pm 0.01^{\mathrm{c}}$ & $1631.90 \pm 0.03$ \\
\hline $10.0-6.0$ & $1022.38 \pm 0.03^{a}$ & $1103.33 \pm 0.01^{c}$ & $1191.43 \pm 0.06^{b}$ & $1300.95 \pm 0.01^{\mathrm{c}}$ & $1329.52 \pm 0.02^{c}$ & $1365.24 \pm 0.01^{\mathrm{c}}$ & $1393.81 \pm 0.03$ \\
\hline
\end{tabular}


Table 3. Cont

\begin{tabular}{|c|c|c|c|c|c|c|c|}
\hline \multirow[b]{2}{*}{$\mathrm{pH}$} & \multirow[b]{2}{*}{$24 \mathrm{~h}$} & \multicolumn{6}{|c|}{ TPC (mg GAE/g PCPC, DW) } \\
\hline & & $48 \mathrm{~h}$ & $72 \mathrm{~h}$ & $96 \mathrm{~h}$ & $120 \mathrm{~h}$ & $144 \mathrm{~h}$ & $168 \mathrm{~h}$ \\
\hline \multicolumn{8}{|c|}{ TPC germinated at $35^{\circ} \mathrm{C}$} \\
\hline $8.0-4.0$ & $1500.95 \pm 0.03^{b}$ & $1170.00 \pm 0.01^{\mathrm{c}}$ & $1355.71 \pm 0.01^{\mathrm{c}}$ & $1396.19 \pm 0.04^{d}$ & $1289.05 \pm 0.05^{b}$ & $1424.76 \pm 0.04^{\mathrm{e}}$ & $1448.57 \pm 0.03^{c}$ \\
\hline $8.0-5.0$ & $1715.24 \pm 0.06^{\mathrm{e}}$ & $979.52 \pm 0.02^{\mathrm{a}}$ & $1227.14 \pm 0.02^{b}$ & $1298.57 \pm 0.04^{\mathrm{c}}$ & $1467.62 \pm 0.06^{\mathrm{c}}$ & $1210.48 \pm 0.04^{b}$ & $1436.67 \pm 0.05^{\mathrm{c}}$ \\
\hline $8.0-6.0$ & $1131.90 \pm 0.03^{\mathrm{a}}$ & $1074.76 \pm 0.02^{b}$ & $1010.48 \pm 0.02^{\mathrm{a}}$ & $936.67 \pm 0.03^{\mathrm{a}}$ & $889.05 \pm 0.03^{a}$ & $984.29 \pm 0.04^{\mathrm{a}}$ & $989.05 \pm 0.03^{a}$ \\
\hline $10.0-4.0$ & $1708.10 \pm 0.02^{\mathrm{e}}$ & $1484.29 \pm 0.02^{\mathrm{d}}$ & $1455.71 \pm 0.02^{d}$ & $1070.00 \pm 0.00^{b}$ & $1446.19 \pm 0.02^{c}$ & $1272.38 \pm 0.02^{c}$ & $1605.71 \pm 0.05^{\mathrm{d}}$ \\
\hline $10.0-5.0$ & $1620.00 \pm 0.00^{d}$ & $1648.57 \pm 0.01^{\mathrm{e}}$ & $1872.38 \pm 0.01^{\mathrm{f}}$ & $1446.19 \pm 0.04^{\mathrm{e}}$ & $1534.29 \pm 0.05^{\mathrm{d}}$ & $1289.05 \pm 0.05^{\mathrm{c}}$ & $1605.71 \pm 0.02^{\mathrm{d}}$ \\
\hline $10.0-6.0$ & $1593.81 \pm 0.03^{c}$ & $1667.62 \pm 0.02^{\mathrm{e}}$ & $1767.62 \pm 0.02^{\mathrm{e}}$ & $1510.48 \pm 0.01^{\mathrm{f}}$ & $1446.19 \pm 0.03^{c}$ & $1327.14 \pm 0.04^{\mathrm{d}}$ & $1174.76 \pm 0.03^{b}$ \\
\hline \multicolumn{8}{|c|}{ TPC germinated at $40^{\circ} \mathrm{C}$} \\
\hline $8.0-4.0$ & $1150.95 \pm 0.04^{\mathrm{c}}$ & $1120.00 \pm 0.06^{b}$ & $605.71 \pm 0.02^{\mathrm{a}}$ & $774.76 \pm 0.04^{c}$ & $917.62 \pm 0.03^{b}$ & $917.62 \pm 0.03^{b}$ & $917.62 \pm 0.03^{b}$ \\
\hline $8.0-5.0$ & $896.19 \pm 0.04^{b}$ & $912.86 \pm 0.04^{\mathrm{a}}$ & $743.81 \pm 0.04^{c}$ & $703.33 \pm 0.03^{b}$ & $955.71 \pm 0.05^{c}$ & $955.71 \pm 0.05^{c}$ & $955.71 \pm 0.02^{c}$ \\
\hline $8.0-6.0$ & $755.71 \pm 0.06^{\mathrm{a}}$ & $1110.48 \pm 0.07^{b}$ & $691.43 \pm 0.06^{b}$ & $674.76 \pm 0.06^{a}$ & $824.76 \pm 0.04^{\mathrm{a}}$ & $824.76 \pm 0.04^{\mathrm{a}}$ & $824.76 \pm 0.08^{a}$ \\
\hline $10.0-4.0$ & $1298.57 \pm 0.04^{\mathrm{e}}$ & $1424.76 \pm 0.09^{d}$ & $1077.14 \pm 0.03^{d}$ & $850.95 \pm 0.03^{d}$ & $974.76 \pm 0.02^{c}$ & $974.76 \pm 0.02^{c}$ & $974.76 \pm 0.01^{c}$ \\
\hline $10.0-5.0$ & $1236.67 \pm 0.04^{d}$ & $1177.14 \pm 0.01^{\mathrm{c}}$ & $1079.52 \pm 0.02^{d}$ & $953.33 \pm 0.06^{\mathrm{e}}$ & $1279.52 \pm 0.05^{\mathrm{e}}$ & $1279.52 \pm 0.05^{\mathrm{e}}$ & $1279.52 \pm 0.01^{\mathrm{e}}$ \\
\hline $10.0-6.0$ & $1327.14 \pm 0.00^{\mathrm{f}}$ & $1053.33 \pm 0.03^{c}$ & $1070.00 \pm 0.03^{d}$ & $924.76 \pm 0.05^{\mathrm{e}}$ & $1117.62 \pm 0.03^{d}$ & $1117.62 \pm 0.03^{d}$ & $1117.62 \pm 0.03^{d}$ \\
\hline
\end{tabular}

Results were expressed as mean \pm standard deviation $(n=3)$ and were evaluated by one-way Anova and Turkey test $(p<0.05)$. Statistical differences were indicated with different letters. 
In the light of the above discussion, we consider that in the protein concentrates obtained from plants, the presence of phenolic in the samples and their possible influence on the biological activities that are evaluated must be considered. For this reason, we decided to name them purple corn protein phenolic concentrates (PCPC).

\subsection{Germinated PCPCs Antioxidant Activity by ABTS and FRAP Methods}

Germinated PCPCs obtained at $\mathrm{pH} 10.0$ of alkaline extraction and $\mathrm{pH} 4.0$ of precipitation, $48-168 \mathrm{~h}$ and $20-40{ }^{\circ} \mathrm{C}$ incubation temperatures were used to evaluate the antioxidant activity by ABTS and FRAP methods. Table 4 showed the PCPCs antioxidant activity values by the ABTS method. PCPCs antioxidant activity values varied between $175.37 \mu \mathrm{mol}$ to $804.35 \mu \mathrm{mol} \mathrm{TE} / \mathrm{g}$ PCPC, DW range. $\mathrm{PCPC} / 35^{\circ} \mathrm{C}$ presented higher values between $196.42 \mu \mathrm{mol}$ to $804.35 \mu \mathrm{mol} \mathrm{TE} / \mathrm{g}$ PCPC, $\mathrm{DW}$. The highest value was registered for $\mathrm{PCPC} / 144 \mathrm{~h} / 35^{\circ} \mathrm{C}$. In general, the high values of antioxidant activities were related to high temperature and time of germination. When compared the groups of temperatures vs. times of germination, statistical differences were observed. Trehan et al. (2018) reported antioxidant activity of yellow, white, and purple corn flours by ABTS and DPPH method. They reported values of 3.81-4.92 $\mu \mathrm{mol} \mathrm{TE} / \mathrm{mg}$ of yellow corn flour, 3.88-4.53 $\mu \mathrm{mol} \mathrm{TE} / \mathrm{mg}$ of white corn flour, and 4.18-4.83 $\mu \mathrm{mol} \mathrm{TE} / \mathrm{mg}$ of purple corn flour. They reported antioxidant activity of purple corn flour using the DPPH method with values of $0.77-0.84 \mu \mathrm{mol} \mathrm{TE} / \mathrm{mg}$ of purple corn flour. These authors reported antioxidant activities of muffins made with yellow, white, and purple corn flours but with lower values than flours [46].

Table 4. PCPC antioxidant activity by the 2,2-azinobis, 3-ethyl-benzothiazoline-6-sulfonic acid, (ABTS) method.

\begin{tabular}{ccccccc}
\hline \multicolumn{7}{c}{ ABTS $(\boldsymbol{\mu m o l}$ TE/g PCPC, DW) } \\
\hline \multicolumn{7}{c}{ Germinated PCPC-pH 10/pH4.0 } \\
\hline Time (h) & $\mathbf{1 5}^{\circ} \mathbf{C}$ & $\mathbf{2 0}^{\circ} \mathbf{C}$ & $\mathbf{2 5}^{\circ} \mathbf{C}$ & $\mathbf{3 0}{ }^{\circ} \mathbf{C}$ & $\mathbf{3 5}^{\circ} \mathbf{C}$ & $\mathbf{4 0}^{\circ} \mathbf{C}$ \\
\hline 24 & $365.20 \pm 0.01^{\mathrm{d}}$ & $323.90 \pm 0.01^{\mathrm{c}}$ & $240.45 \pm 0.01^{\mathrm{b}}$ & $497.00 \pm 0.05^{\mathrm{d}}$ & $564.44 \pm 0.09^{\mathrm{a}}$ & $619.18 \pm 0.05^{\mathrm{f}}$ \\
48 & $364.20 \pm 0.01^{\mathrm{d}}$ & $348.62 \pm 0.01^{\mathrm{c}}$ & $242.08 \pm 0.09^{\mathrm{b}}$ & $246.02 \pm 0.05^{\mathrm{a}}$ & $407.71 \pm 0.10^{\mathrm{d}}$ & $546.10 \pm 0.02^{\mathrm{e}}$ \\
72 & $618.48 \pm 0.04^{\mathrm{c}}$ & $531.55 \pm 0.02^{\mathrm{d}}$ & $496.20 \pm 0.03^{\mathrm{c}}$ & $453.34 \pm 0.03^{\mathrm{c}}$ & $506.91 \pm 0.06^{\mathrm{e}}$ & $215.52 \pm 0.06^{\mathrm{a}}$ \\
96 & $603.87 \pm 0.03^{\mathrm{c}}$ & $234.06 \pm 0.01^{\mathrm{b}}$ & $246.06 \pm 0.03^{\mathrm{b}}$ & $417.63 \pm 0.03^{\mathrm{b}}$ & $196.42 \pm 0.03^{\mathrm{a}}$ & $498.61 \pm 0.05^{\mathrm{d}}$ \\
120 & $490.21 \pm 0.09^{\mathrm{b}}$ & $197.87 \pm 0.06^{\mathrm{a}}$ & $570.97 \pm 0.07^{\mathrm{d}}$ & $493.02 \pm 0.04^{\mathrm{d}}$ & $402.75 \pm 0.09^{\mathrm{c}}$ & $404.77 \pm 0.07^{\mathrm{b}}$ \\
144 & $407.21 \pm 0.09^{\mathrm{a}}$ & $562.68 \pm 0.02^{\mathrm{e}}$ & $175.37 \pm 0.01^{\mathrm{a}}$ & $547.58 \pm 0.02^{\mathrm{e}}$ & $804.35 \pm 0.08^{\mathrm{e}}$ & $488.44 \pm 0.05^{\mathrm{d}}$ \\
168 & $490.45 \pm 0.09^{\mathrm{b}}$ & $571.49 \pm 0.09^{\mathrm{e}}$ & $603.60 \pm 0.03^{\mathrm{e}}$ & $278.57 \pm 0.06^{\mathrm{a}}$ & $235.10 \pm 0.04^{\mathrm{b}}$ & $470.05 \pm 0.01^{\mathrm{c}}$ \\
\hline
\end{tabular}

Results are expressed as mean \pm standard deviation $(n=3)$ and were evaluated by one-way Anova and Turkey test $(p<0.05)$. Statistical differences were indicated with different letters.

Table 5 showed the results obtained of PCPCs antioxidant activity by the FRAP method. The samples showed values with 100.46 to $984.83 \mu \mathrm{mol}$ TE/g PCPC, DW. The higher value was observed for PCPC/144 h/30 ${ }^{\circ} \mathrm{C}$ with $984.83 \mu \mathrm{mol} \mathrm{TE} / \mathrm{g}$ PCPC, DW. Germinated PCPC at $35{ }^{\circ} \mathrm{C}$ presented values between $168.25 \mu \mathrm{mol}$ to $922.25 \mu \mathrm{mol}$ TE/g PCPC, DW. In general, higher antioxidant activities were observed for similar behavior at high temperatures and high germination times presenting higher antioxidant activity. Statistical analysis showed significant differences when the groups of temperatures were compared to the incubation times at $p<0.05$. Coco and Vinson (2019) reported antioxidant activity of raw kernel $8.73-13.40 \mathrm{mg}$ of catechin/g for nine varieties of corn by the FRAP method. Raw kernel was subjected to in vitro simulation digestion. The antioxidant activity was evaluated by the FRAP method. They found a value of $0.76 \mathrm{mg}$ catechin/g of sample [65]. Yang and Zhai (2010) reported antioxidant activity of total anthocyanins content (TAC) isolated from purple corn kernels using the DPPH, FRAP, and TEAC methods (16.20 mmol and $18.70 \mathrm{mmol}$ of $\left.\mathrm{FeSO}_{4} / \mathrm{g} \mathrm{DW}\right)$. 
Table 5. PCPC antioxidant activity by the ferric-reducing antioxidant power (FRAP) method.

\begin{tabular}{ccccccc}
\hline \multicolumn{7}{c}{ FRAP ( $\mu$ mol TE/g PCPC, DW) } \\
\hline \multicolumn{7}{c}{ Germinated PCPC pH 10-pH 4.0 } \\
\hline Time (h) & $\mathbf{1 5}^{\circ} \mathbf{C}$ & $\mathbf{2 0}^{\circ} \mathbf{C}$ & $\mathbf{2 5}^{\circ} \mathbf{C}$ & $\mathbf{3 0}^{\circ} \mathbf{C}$ & $\mathbf{3 5}^{\circ} \mathbf{C}$ & $\mathbf{4 0}^{\circ} \mathbf{C}$ \\
\hline 24 & $257.98 \pm 0.01^{\mathrm{c}}$ & $208.58 \pm 0.01^{\mathrm{a}}$ & $154.86 \pm 0.01^{\mathrm{a}}$ & $155.52 \pm 0.93^{\mathrm{a}}$ & $168.25 \pm 3.33^{\mathrm{a}}$ & $173.61 \pm 0.01^{\mathrm{a}}$ \\
48 & $243.44 \pm 0.01^{\mathrm{c}}$ & $243.40 \pm 0.01^{\mathrm{b}}$ & $165.11 \pm 0.02^{\mathrm{a}}$ & $454.86 \pm 0.01^{\mathrm{a}}$ & $771.68 \pm 0.67^{\mathrm{c}}$ & $611.19 \pm 0.09^{\mathrm{c}}$ \\
72 & $741.49 \pm 0.09^{\mathrm{d}}$ & $770.21 \pm 0.21^{\mathrm{d}}$ & $678.18 \pm 0.10^{\mathrm{d}}$ & $815.04 \pm 0.20^{\mathrm{c}}$ & $922.25 \pm 0.52^{\mathrm{d}}$ & $628.94 \pm 0.70^{\mathrm{c}}$ \\
96 & $807.29 \pm 0.09^{\mathrm{e}}$ & $339.15 \pm 0.36^{\mathrm{b}}$ & $335.36 \pm 0.91^{\mathrm{c}}$ & $750.69 \pm 0.44^{\mathrm{b}}$ & $349.39 \pm 0.02^{\mathrm{a}}$ & $552.42 \pm 0.59^{\mathrm{b}}$ \\
120 & $100.46 \pm 0.21^{\mathrm{a}}$ & $286.71 \pm 0.69^{\mathrm{c}}$ & $772.85 \pm 0.29^{\mathrm{c}}$ & $877.92 \pm 0.36^{\mathrm{d}}$ & $747.02 \pm 0.09^{\mathrm{c}}$ & $452.69 \pm 0.06^{\mathrm{a}}$ \\
144 & $121.00 \pm 0.21^{\mathrm{b}}$ & $751.10 \pm 0.49^{\mathrm{d}}$ & $236.10 \pm 1.52^{\mathrm{b}}$ & $984.83 \pm 0.38^{\mathrm{e}}$ & $363.58 \pm 0.51^{\mathrm{a}}$ & $699.23 \pm 3.17^{\mathrm{d}}$ \\
168 & $120.01 \pm 0.21^{\mathrm{b}}$ & $800.83 \pm 0.30^{\mathrm{e}}$ & $817.12 \pm 0.55^{\mathrm{e}}$ & $762.63 \pm 0.13^{\mathrm{b}}$ & $435.30 \pm 0.38^{\mathrm{b}}$ & $701.44 \pm 0.35^{\mathrm{e}}$ \\
\hline
\end{tabular}

Results are expressed as mean \pm standard deviation $(n=3)$ and were evaluated by one-way Anova and Turkey test $(p<0.05)$. Statistical differences were indicated with different letters.

Various researchers have reported a relationship between polyphenol and anthocyanin content of purple corn kernels and their antioxidant activities [4]. López-Martinez et al. (2014) described antioxidant activity of three varieties of purple corn using nitric oxide radical scavenging activity and superoxide radical scavenging activity methods. The ethanol extracts showed a strong antioxidant activity in the following order: generic purple > Oaxaca $332>$ Veracruz 42 with $62.00 \%, 48.00 \%$, and $32.00 \%$ of NO scavenging activity, respectively [66].

The protocol used in this study to obtain antioxidant PCPC was validated from a lot of seeds of Andean purple corn of the variety (Zea mays L., INIAP-199 bunch of grapes) grown in Guaranda, Ecuador. The proteins and polyphenols content present in seeds can vary with the variety tested and the seeds growing conditions. For this reason, this protocol could be validated with different varieties of corn seeds (purple, white, and yellow corn) grown under different environmental conditions, different irrigation conditions, and different fertilization conditions. The protocol could also be validated on transgenic corn seeds to compare the results.

\section{Conclusions}

Andean purple seeds can be germinated in a wide range of temperatures $\left(15-40{ }^{\circ} \mathrm{C}\right)$ and times (24-168 h). Alkaline extraction ( $\mathrm{pH} 8.0$ and $\mathrm{pH} 10)$ followed by the isoelectric precipitation ( $\mathrm{pH} 4.0$, $\mathrm{pH} 5.0$, and $\mathrm{pH} 6.0$ ) is a good method to obtain protein phenolic corn concentrate (PCPC). A higher concentration of protein and TPC can be obtained in PCPC compared with non-germinated corn kernel flours. The germination process of Andean purple corn kernels can be used to obtain PCPC with biological activities, such as antioxidant activity, that can increase the nutritional value and quality of this food product. The germinated purple corn PCPCs have a high content of phenolic components that are responsible for the antioxidant activity. The protocol used to obtain antioxidant PCPCs in this study is a preliminary protocol that must be tested in different varieties of corn seeds grown under different environmental conditions. This protocol needs to consider the influence of the dormancy stages of the seeds.

Author Contributions: Conceptualization, A.G., W.C., and E.V.; methodology, E.V., M.V., W.C., and A.G.; validation, R.M., E.V., M.V., and I.S.; formal analysis, R.M., M.V., and E.V.; investigation, E.V., M.V., and R.M.; writing — original draft preparation, W.C.; writing — review and editing, W.C. All authors have read and agreed to the published version of the manuscript.

Funding: This research received no external funding.

Acknowledgments: The authors thank the Debt Swap project (Spain-Ecuador) of the Bolívar State University.

Conflicts of Interest: The authors declare no conflict of interest. 


\section{References}

1. FAOSTAT 2018 Food and Agriculture Organization Corporate Statistical Database. Available online: http://faostat.fao.org (accessed on 1 May 2020).

2. Cuevas-Rodríguez, E.O.; Verdugo-Montoya, N.M.; Angulo-Bejarano, P.I.; Milan-Carrillo, J.; Mora-Escobedo, R.; Bello-Pérez, L.A.; Garzón-Tiznado, J.A.; Reyes-Moreno, C. Nutritional properties of tempeh flour from quality protein maize (Zea mays L.). LWT Food Sci. Technol. 2006, 39, 1072-1079. [CrossRef]

3. Ul-Allah, S.; Ijaz, M.; Nawaz, A.; Sattar, A.; Sher, A.; Naeem, M.; Shahzad, U.; Nawaz, F.; Mahmood, K. Potassium Application Improves Grain Yield and Alleviates Drought Susceptibility in Diverse Maize Hybrids. Plants 2020, 9, 75. [CrossRef] [PubMed]

4. Yang, Z.; Zhai, W. Identification and antioxidant activity of anthocyanins extracted from the seed and cob of purple corn (Zea mays L.). Innov. Food Sci. Emerg. Technol. 2010, 11, 169-176. [CrossRef]

5. Mrad, R.; Debs, E.; Saliba, R.; Maroun, R.G.; Louka, N. Multiple optimization of chemical and textural properties of roasted expanded purple maize using response surface methodology. J. Cereal Sci. 2014, 60, 397-405. [CrossRef]

6. Kabir, S.H.; Das, A.K.; Rahman, M.S.; Singh, S.K.; Morshed, M.; Marma, A.S.H. Effect of genotype on proximate composition and biological yield of maize (Zea mays L.). AAES 2019, 4, 185-189. [CrossRef]

7. Moreira, R.; Chenlo, F.; Arufe, S.; Rubinos, S.N. Physicochemical characterization of white, yellow and purple maize flours and rheological characterization of their doughs. J. Food Sci. Technol. 2015, 52, 7954-7963. [CrossRef] [PubMed]

8. Govender, V.; Aveling, T.A.S.; Kritzinger, Q. The effect of traditional storage methods on germination and vigour of maize (Zea mays L.) from northern KwaZulu-Natal and southern Mozambique. S. Afr. J. Bot. 2008, 74, 190-196. [CrossRef]

9. Cuevas-Rodríguez, E.O.; Milán-Carrillo, J.; Mora-Escobedo, R.; Cárdenas-Valenzuela, O.G.; Reyes-Moreno, C. Quality protein maize (Zea mays L.) tempeh flour through solid state fermentation process. LWT-Food Sci. Technol. 2004, 37, 59-67. [CrossRef]

10. Wang, Y.; King, J.M.; Xu, Z.; Losso, J.; Prudente, A. Lutein from ozone-treated corn retains antimutagenic properties. J. Agric. Food Chem. 2008, 56, 7942-7949. [CrossRef]

11. Carrillo, W.; Carpio, C.; Morales, D.; Vilcacundo, E.; Alvarez, M.; Silva, M. Content of fatty acids in corn (Zea mays L.) oil from Ecuador. Asian J. Pharm. Clin. Res. 2017, 10, 150-153.

12. Wang, X.F.; Jing, X.M.; Lin, J. Starch mobilization in ultra-dried seed of maize (Zea mays L.) during germination. J. Integr. Plant Biol. 2005, 47, 443-451. [CrossRef]

13. López-Martínez, L.X.; Leyva-López, N.; Gutiérrez-Grijalva, E.P.; Heredia, J.B. Effect of cooking and germination on bioactive compounds in pulses and their health benefits. J. Funct. Foods 2017, 38, 624-634. [CrossRef]

14. Han, Z.; Wang, B.; Tian, L.; Wang, S.; Zhang, J.; Guo, S.; Zhang, H.; Xu, L.; Chen, Y. Comprehensive dynamic transcriptome analysis at two seed germination stages in maize (Zea mays L.). Physiol. Plant. 2020, 168, 205-217. [CrossRef]

15. Sokrab, A.M.; Ahmed, I.A.M.; Babiker, E.E. Effect of germination on antinutritional factors, total, and extractable minerals of high and low phytate corn (Zea mays L.) genotypes. J. Saudi Soc. Agric. Sci. 2012, 11, 123-128. [CrossRef]

16. Aguilera, Y.; Díaz, M.F.; Jiménez, T.; Benítez, V.; Herrera, T.; Cuadrado, C.; Martín-Cabrejas, M.A. Changes in non-nutritional factors and antioxidant activity during germination of nonconventional legumes. J. Agric. Food Chem. 2013, 61, 8120-8125. [CrossRef] [PubMed]

17. Mbithi, S.; Van Camp, J.; Rodriguez, R.; Huyghebaert, A. Effects of sprouting on nutrient and antinutrient composition of kidney beans (Phaseolus vulgaris var. Rose coco). Eur. Food Res. Technol. 2001, 212, 188-191. [CrossRef]

18. Benítez, V.; Cantera, S.; Aguilera, Y.; Mollá, E.; Esteban, R.M.; Díaz, M.F.; Martín-Cabrejas, M.A. Impact of germination on starch, dietary fiber and physicochemical properties in non-conventional legumes. Food Res. Int. 2013, 50, 64-69. [CrossRef] 
19. Carrillo, W.; Gómez-Ruiz, J.A.; Miralles, B.; Ramos, M.; Barrio, D.; Recio, I. Identification of antioxidant peptides of hen egg-white lysozyme and evaluation of inhibition of lipid peroxidation and cytotoxicity in the Zebrafish model. Eur. Food Res. Technol. 2016, 242, 1777-1785. [CrossRef]

20. Piñuel, L.; Vilcacundo, E.; Boeri, P.; Barrio, D.A.; Morales, D.; Pinto, A.; Morán, R.; Samaniego, I.; Carrillo, W. Extraction of protein concentrate from red bean (Phaseolus vulgaris L.): Antioxidant activity and inhibition of lipid peroxidation. J. Appl. Pharm. Sci. 2019, 9, 1-14.

21. Vilcacundo, R.; Barrio, D.; Carpio, C.; García-Ruiz, A.; Rúales, J.; Hernández-Ledesma, B.; Carrillo, W. Digestibility of quinoa (Chenopodium quinoa Willd) protein concentrate and its potential to inhibit lipid peroxidation in the Zebrafish larvae model. Plant Foods Hum. Nutr. 2017, 72, 294-300. [CrossRef]

22. Saito, M.; Sakagami, H.; Fujisawa, S. Cytotoxicity and apoptosis induction by butylated hydroxyanisole (BHA) and butylated hydroxytoluene (BHT). Anticancer Res. 2003, 23, 4693-4701. [PubMed]

23. Nieva-Echevarría, B.; Manzanos, M.J.; Goicoechea, E.; Guillén, M.D. 2,6-Di-tert-butyl-hydroxytoluene and its metabolites in foods. Compr. Rev. Food Sci. Food Saf. 2015, 14, 67-80. [CrossRef]

24. Gawlik-Dziki, U.; Świeca, M.; Sułkowski, M.; Dziki, D.; Baraniak, B.; Czyż, J. Antioxidant and anticancer activities of Chenopodium quinoa leaves extracts-in vitro study. Food Chem. Toxicol. 2013, 57, 154-160. [CrossRef] [PubMed]

25. Vilcacundo, R.; Miralles, B.; Carrillo, W. Hernández-Ledesma B in vitro chemopreventive properties of peptides released from quinoa (Chenopodium quinoa Willd) protein under simulated gastrointestinal digestion. Food Res. Int. 2018, 105, 403-411. [CrossRef] [PubMed]

26. Vilcacundo, R.; Barrio, D.A.; Piñuel, L.; Boeri, P.; Tombari, A.; Welbaum, J.; Pinto, A.; Hernández-Ledesma, B.; Carrillo, W. Inhibition of lipid peroxidation of kiwicha (Amaranthus caudatus) hydrolyzed protein using zebrafish larvae and embryos. Plants 2018, 7, 69. [CrossRef] [PubMed]

27. Das, A.K.; Singh, V. Antioxidative free and bound phenolic constituents in pericarp, germ and endosperm of Indian dent (Zea mays var. indentata) and flint (Zea mays var. indurata) maize. J. Funct. Foods 2015, 13, 363-374. [CrossRef]

28. Lao, F.; Sigurdson, G.T.; Giusti, M.M. Health benefits of purple corn (Zea mays L.) phenolic compounds. Compr. Rev. Food Sci. Food Saf. 2017, 16, 234-246. [CrossRef]

29. Zhang, Q.; de Mejia, E.G.; Luna-Vital, D.; Tao, T.; Chandrasekaran, S.; Chatham, L.; Kumar, D. Relationship of phenolic composition of selected purple maize (Zea mays L.) genotypes with their anti-inflammatory, anti-adipogenic and anti-diabetic potential. Food Chem. 2019, 89, 739-750. [CrossRef]

30. Dueñas, M.; Martiínez-Villaluenga, C.; Limón, R.I.; Peñas, E.; Frias, J. Effect of germination and elicitation on phenolic composition and bioactivity of kidney beans. Food Res. Int. 2015, 70, 55-63. [CrossRef]

31. González-Montoya, M.; Hernández-Ledesma, B.; Silván, J.M.; Mora-Escobedo, R.; Martínez-Villaluenga, C. Peptides derived from in vitro gastrointestinal digestion of germinated soybean proteins inhibit human colon cancer cells proliferation and inflammation. Food Chem. 2018, 242, 75-82. [CrossRef]

32. De Souza Rocha, T.; Hernandez, L.M.R.; Mojica, L.; Johnson, M.H.; Chang, Y.K.; de Mejía, E.G. Germination of Phaseolus vulgaris and alcalase hydrolysis of its proteins produced bioactive peptides capable of improving markers related to type-2 diabetes in vitro. Food Res. Int. 2015, 76, 150-159. [CrossRef]

33. Mamilla, R.K.; Mishra, V.K. Effect of germination on antioxidant and ACE inhibitory activities of legumes. LWT Food Sci. Technol. 2017, 75, 51-58. [CrossRef]

34. López-Amorós, M.L.; Hernández, T.; Estrella, I. Effect of germination on legume phenolic compounds and their antioxidant activity. J. Food Comp. Anal. 2006, 19, 277-283. [CrossRef]

35. Cornejo, F.; Novillo, G.; Villacrés, E.; Rosell, C.M. Evaluation of the physicochemical and nutritional changes in two amaranth species (Amaranthus quitensis and Amaranthus caudatus) after germination. Food Res. Int. 2019, 121, 933-939. [CrossRef]

36. Piñuel, L.; Boeri, P.; Zubillaga, F.; Barrio, D.A.; Torreta, J.; Cruz, A.; Vásquez, G.; Pinto, A.; Carrillo, W. Production of White, Red and Black Quinoa (Chenopodium quinoa Willd Var. Real) Protein Isolates and Its Hydrolysates in Germinated and Non-Germinated Quinoa Samples and Antioxidant Activity Evaluation. Plants 2019, 8, 257. [CrossRef]

37. AOAC. Association of Official Analytical Chemists AOAC, Official Methods of Analysis, 18th ed.; AOAC: Gaithersburg, MD, USA, 2012.

38. Instituto Ecuatoriano de Normalización (INEN). Frutas Frescas Tomate de árbol, Requisitos; INEN 1909; Norma Técnica Ecuatoriana: Quito, Ecuador, 2013; p. 12. 
39. Paucar-Menacho, L.M.; Martinez-Villaluenga, C.; Dueñas, M.; Frias, J.; Peñas, E. Optimization of germination time and temperature to maximize the content of bioactive compounds and the antioxidant activity of purple corn (Zea mays L.) by response surface methodology. LWT Food Sci. Technol. 2017, 76, 236-244. [CrossRef]

40. Acosta, C.; Carpio, C.; Vilcacundo, R.; Carrillo, W. Identification of proteins isolate from amaranth (Amaranthus caudatus) by sodium dodecyl sulfate-polyacrylamide gel electrophoresis with water and $\mathrm{NaCl} 0.1 \mathrm{M}$ solvents. Asian J. Pharm. Clin. Res. 2016, 9, 331-333.

41. Serrano, S.; Rincón, F.; García-Olmo, J. Cereal protein analysis via Dumas method: Standardization of a micro-method using the Euro vector elemental analyzer. J. Cereal Sci. 2013, 58, 31-36. [CrossRef]

42. Poveda, T.; Vilcacundo, R.; Carpio, C.; Carrillo, W. Analysis of sesame proteins isolate (Sesamum indicum L.) with water and salt treatment. Asian J. Pharm. Clin. Res. 2016, 9, 404-407.

43. Lara, D.; Vilcacundo, E.; Carrillo, C.; Silva, M.; Alvarez, M.; Carpio, C.; Carrillo, W. Obtention of protein concentrate and polyphenols from macadamia (Macadamia integrifolia) with aqueous extraction method. Asian J. Pharm. Clin. Res. 2017, 10, 138-142.

44. Boeri, P.; Piñuel, L.; Dalzotto, D.; Monasterio, R.; Fontana, A.; Sharry, S.; Barrio, D.A.; Carrillo, W. Argentine Patagonia barberry chemical composition and evaluation of its antioxidant capacity. J. Food Biochem. 2020. [CrossRef] [PubMed]

45. Zambrano, M.; Vásquez, G.; Morales, D.; Vilcacundo, R.; Carrillo, W. Isolation of baby lima bean (Phaseolus lunatus) proteins fractions and evaluation of their antioxidant activity. Ital. J. Food Sci. 2020, 32. [CrossRef]

46. Trehan, S.; Singh, N.; Kaur, A. Characteristics of white, yellow, purple corn accessions: Phenolic profile, textural, rheological properties and muffin making potential. J. Food Sci. Technol. 2018, 55, 2334-2343. [CrossRef] [PubMed]

47. Mansilla, P.S.; Nazar, M.C.; Pérez, G.T. Flour functional properties of purple maize (Zea mays L.) from Argentina. Influence of environmental growing conditions. Int. J. Biol. Macromol. 2020, 146, 311-319. [CrossRef] [PubMed]

48. Wu, Y.; Messing, J. Proteome balancing of the maize seed for higher nutritional value. Front. Plant Sci. 2014, 5, 240. [CrossRef] [PubMed]

49. Esen, A. A proposed nomenclature for the alcohol-soluble proteins (zeins) of maize (Zea mays L.). J. Cereal Sci. 1987, 5, 117-128. [CrossRef]

50. Coleman, C.E.; Larkins, B.A. The prolamins of maize. In Seed Proteins; Shewry, P.R., Casey, R., Eds.; Kluwer Academic Publishers: Dordrecht, The Netherlands, 1998; pp. 109-139.

51. Mertz, E.T.; Bates, L.S.; Nelson, O.E. Mutant gene that changes protein composition and increases lysine content of maize endosperm. Science 1964, 145, 279-280. [CrossRef]

52. Esen, A. Separation of alcohol-soluble proteins (zeins) from maize into three fractions by differential solubility. Plant Physiol. 1986, 80, 623-627. [CrossRef]

53. Lai, H.M.; Padua, G.W.; Wei, L.S. Properties and microstructure of zein sheets plasticized with palmitic and stearic acids. Cereal Chem. 1997, 74, 83-90. [CrossRef]

54. Shukla, R.; Cheryan, M. Zein: The industrial protein from corn. Ind. Crops Prod. 2001, 13, 171-192. [CrossRef]

55. Swallen, L.C. Zein. A new industrial protein. Ind. Eng. Chem. 1941, 33, 394-398. [CrossRef]

56. Sharif, N.; Fabra, M.J.; López-Rubio, A. Nanostructures of zein for encapsulation of food ingredients. In Biopolymer Nanostructures for Food Encapsulation Purposes; Academic Press: New York, NY, USA, 2019; pp. 217-245.

57. Zhang, M.; Reitmeier, C.A.; Hammond, E.G.; Myers, D.J. Production of textile fibers from zein and a soy protein-zein blend. Cereal Chem. 1997, 74, 594-598. [CrossRef]

58. Morawsky, N.; Martino, G.T.; Guth, J.; Tsai, J.; Jeffcoat, R. Hydrolyzed Zein as Fixative in Hair Compositions. U.S. Patent 5,518,717, 21 May 1996.

59. Mathiowitz, E.; Bernstein, H.; Morrel, E.; Schwaller, K. Method for Producing Protein Microspheres. U.S. Patent WO 91/06286, 16 May 1991.

60. Peres, A.E.C.; Correa, M.I. Depression of iron oxides with corn starches. Miner. Eng. 1996, 9, 1227-1234. [CrossRef]

61. Trezza, T.A.; Vergano, P.J. Grease resistance of corn zein coated paper. J. Food Sci. 1994, 59, 912-915. [CrossRef]

62. Wang, J.Y.; Miyazawa, T.; Fujimoto, K. Inhibition of methyl linoleate peroxidation by maize zein in powder model system at high water activity. Agric. Biol. Chem. 1991, 55, 1531-1536. 
63. De la Parra, C.; Serna Saldivar, S.O.; Liu, R.H. Effect of processing on the phytochemical profiles and antioxidant activity of corn for production of masa, tortillas, and tortilla chips. J. Agric. Food Chem. 2007, 55, 4177-4183. [CrossRef] [PubMed]

64. Mora-Rochin, S.; Gutiérrez-Uribe, J.A.; Serna-Saldivar, S.O.; Sánchez-Peña, P.; Reyes-Moreno, C.; Milán-Carrillo, J. Phenolic content and antioxidant activity of tortillas produced from pigmented maize processed by conventional nixtamalization or extrusion cooking. J. Cereal Sci. 2010, 52, 502-508. [CrossRef]

65. Coco, M.G.; Vinson, J.A. Analysis of Popcorn (Zea Mays L. var. Everta) for Antioxidant Capacity and Total Phenolic Content. Antioxidants 2019, 8, 22. [CrossRef]

66. Lopez-Martinez, L.X.; Parkin, K.L.; Garcia, H.S. Antioxidant and quinone reductase inducing activities of ethanolic fractions from purple maize. LWT Food Sci. Technol. 2014, 59, 270-275. [CrossRef]

C 2020 by the authors. Licensee MDPI, Basel, Switzerland. This article is an open access article distributed under the terms and conditions of the Creative Commons Attribution (CC BY) license (http://creativecommons.org/licenses/by/4.0/). 